

\section{Daftar Isi (Table of Content) Journal of Government
Civil Society}

\begin{tabular}{|c|c|}
\hline \multirow{3}{*}{$1-34$} & $\begin{array}{l}\text { Akuntabilitas Politik dalam Anggaran (Studi Kasus: Dana Gerakan Dusun } \\
\text { Membangun (GDM) di Kabupaten Bungo) }\end{array}$ \\
\hline & Fajar Trilaksana Moedarlis \\
\hline & (Magister Ilmu Pemerintahan, Universitas Muhammadiyah Yogyakarta, Indonesia) \\
\hline \multirow[b]{3}{*}{$35-46$} & $\begin{array}{l}\text { Civil Servants Performance Analysis of Education, Youth and Sports } \\
\text { Department in Bantul District } 2017\end{array}$ \\
\hline & Surya Jaya Abadi ${ }^{1}$, Muhammad Eko Atmojo ${ }^{2}$, Helen Dian Fridayani ${ }^{3}$ \\
\hline & $\begin{array}{l}\left({ }^{1} \text { Government Affairs and Administration, Universitas Muhammadiyah Yogyakarta, }\right. \\
\text { Indonesia) } \\
\text { ('2Government Affairs and Administration, Universitas Muhammadiyah Yogyakarta, } \\
\text { Indonesia) } \\
\text { ('3overnment Affairs and Administration, Universitas Muhammadiyah Yogyakarta, } \\
\text { Indonesia) }\end{array}$ \\
\hline \multirow{3}{*}{$47-61$} & $\begin{array}{l}\text { Efektivitas Pengawasan Badan Pengawas Obat dan Makanan (BPOM) } \\
\text { terhadap Peredaran Makanan Impor oleh Pedagang UMKM di Kota } \\
\text { Pekanbaru }\end{array}$ \\
\hline & Ferry Angriawan1, Dyah Mutiarin² \\
\hline & $\begin{array}{l}\text { ('Magister Ilmu Pemerintahan, Universitas Muhammadiyah Yogyakarta, Indonesia) } \\
\left({ }^{2} \text { Magister Ilmu Pemerintahan, Universitas Muhammadiyah Yogyakarta, Indonesia) }\right.\end{array}$ \\
\hline \multirow{3}{*}{$63-78$} & $\begin{array}{l}\text { Institusionalisasi Partai Politik dalam Pilkada } 2017 \text { (Studi Kasus: Partai } \\
\text { Golkar Provinsi Kepulauan Bangka Belitung) }\end{array}$ \\
\hline & Agam Primadi ${ }^{1}$, Titin Purwaningsih ${ }^{2}$ \\
\hline & $\begin{array}{l}\left({ }^{1} \text { Magister Ilmu Pemerintahan, Universitas Muhammadiyah Yogyakarta, Indonesia) }\right. \\
\left({ }^{2} \text { Magister Ilmu Pemerintahan, Universitas Muhammadiyah Yogyakarta, Indonesia) }\right.\end{array}$ \\
\hline \multirow[b]{3}{*}{$79-91$} & $\begin{array}{l}\text { Public Value in Clean Water Management at the Local Water Supply Utility } \\
\text { (PDAM) Tirta Kerta Raharja (TKR) }\end{array}$ \\
\hline & Arsid $^{1}$, Ida Widianingsih'², Heru Nurasa ${ }^{3}$, Entang Adhy Muhtar ${ }^{4}$ \\
\hline & $\begin{array}{l}\text { ('Mahasiswa Program Pascasarjana Administrasi Publik, FISIP Universitas Padjadjaran, } \\
\text { Indonesia) } \\
\text { ('Pusat Studi Desentralisasi dan Pembangunan Partisipatif, FISIP Universitas } \\
\text { Padjadjaran, Indonesia) } \\
\text { ('Departemen Administrasi Publik, FISIP Universitas Padjadjaran, Indonesia) } \\
\left({ }^{4} \text { Departemen Administrasi Publik, FISIP Universitas Padjadjaran, Indonesia) }\right.\end{array}$ \\
\hline
\end{tabular}




\title{
Public Value in Clean Water Management at the Local Water Supply Utility (PDAM) Tirta Kerta Raharja (TKR)
}

\author{
Arsid $^{1}$, Ida Widianingsih ${ }^{2}$, Heru Nurasa ${ }^{3}$, Entang Adhy Muhtar ${ }^{4}$ \\ ${ }^{1}$ Mahasiswa Program Pascasarjana Administrasi Publik, FISIP Universitas Padjadjaran, Indonesia \\ Email: arsidtangsel2017@gmail.com
}

${ }^{2}$ Pusat Studi Desentralisasi dan Pembangunan Partisipatif, FISIP Universitas Padjadjaran, Indonesia Email: ida.widianingsih@unpad.ac.id

${ }^{3}$ Departemen Administrasi Publik, FISIP Universitas Padjadjaran, Indonesia Email: hnurasa@yahoo.com

${ }^{4}$ Departemen Administrasi Publik, FISIP Universitas Padjadjaran, Indonesia Email: entang.am0405@gmail.com

\begin{abstract}
As a strategic commodity, Indonesia's constitution mandates the management of clean water to the local government through the Local Water Supply Utility (PDAM) which is also regulated in PP No. 122/2015 concerning Drinking Water Supply Systems. However, the availability of inadequate clean water as well as the limited ability to manage clean water have caused the minimum service target to be optimal in providing clean water. Using Mark Moore's public value theory, this study aims to determine how the public value of PDAM TKR (Tirta Kerta Raharja) in Tangerang District. This study uses a qualitative approach. Data collection techniques used were observation, in-depth interviews, and documentation studies. The results of the study show that PDAM TKR's public value has not been internalized optimally, and it requires adaptation to changes in the organizational environment. In addition, the diverse customer characteristics of PDAM TKR require specific strategies to respond to their needs.
\end{abstract}

Keywords: Clean water service, public value, PDAM TKR (Tangerang District)

\begin{abstract}
ABSTRAK
Sebagai komoditas yang strategis, konstitusi Indonesia mengamanatkan pengelolaan air bersih kepada pemerintah daerah melalui Perusahaan Daerah Air Minum (PDAM) yang juga diatur dalam PP No. 122/2015 tentang Sistem Penyediaan Air Minum. Akan tetapi, ketersediaan air bersih yang belum memadai serta keterbatasan kemampuan mengelola air bersih menyebabkan tidak optimalnya target pelayanan minimum dalam penyediaan air bersih. Menggunakan teori nilai publik (public value) milik Mark Moore, penelitian ini bertujuan untuk mengetahui bagaimana public value pada PDAM TKR Kabupaten Tangerang. Penelitian ini menggunakan pendekatan kualitatif. Teknik pengumpulan data yang digunakan adalah observasi, wawancara mendalam, dan studi dokumentasi. Hasil penelitian menunjukkan bahwa public value PDAM TKR belum terinternalisasi secara optimal, dan dibutuhkan adaptasi terhadap perubahan di lingkungan organisasi. Selain itu, karakteristik pelanggan PDAM TKR yang beragam membutuhkan strategi khusus dalam merespon kebutuhan mereka.
\end{abstract}

Kata Kunci: Pelayanan air bersih, public value, PDAM TKR (Kabupaten Tangerang)

Citation : Arsid, Ida Widianingsih, Heru Nurasa dan Entang Adhy Muhtar. 2019. "Public Value in Clean Water Management at the Local Water Supply Utility (PDAM) Tirta Kerta Raharja (TKR)". Journal of Government and Civil Society, Vol. 3, No. 1, 79-91. 


\section{INTRODUCTION}

Local Water Supply Utility (PDAM), as a local government-owned enterprise that provides services and public benefits in the water sector, was formed through Law No. 5 of 1962. In the current era of decentralization, the regulation is strengthened by PP No . 122/2015 concerning Drinking Water Supply Systems to ensure the availability of quality drinking water at affordable prices for the wider community. At present, PDAM is a Regional Owned Enterprise (BUMD) that has a "dual function", namely balancing business interests while fulfilling obligations in serving the general public.

In 2017, the coverage of clean water services in Indonesia has only reached $70.04 \%$ of all population (Ministry of PUPR, 2018). This is reinforced by data from the PDAM performance evaluation in 2017 carried out by BPPSPAM and BPKP toward 378 PDAMs in regencies/cities in Indonesia. The data is a recapitulation of the performance of 378 PDAMs in 2014, 2015 and 2016 from financial, service, operational and human resources aspects. The evaluation results showed that 209 PDAMs (55.3\%) were declared healthy, 103 PDAMs (27.2\%) were declared unhealthy and 66 PDAMs (17.5\%) were declared ill (Ministry of PUPR, 2017).

Basically, the ability to provide drinking water is very possible, because until 2018 the recorded capacity is 38.000 liters per second. The Ministry of PUPR targets the completion of the service gap for clean water coverage (28\%) within two years until 2019 through a protected pipeline and non-network pipeline network. This is also to support the 20152019 RPJMN which mandates the achievement of $100 \%$ safe access to drinking water for all Indonesian people in 2019 (Ministry of PUPR, 2018). To make it happen, the government needs 253.8 trillion from various funding sources: the state budget, regional budgets, DAK, business entities through the scheme of Public Private Partnership (PPP), banking, CSR, and the community.

In Tangerang District itself, the need for clean water has increased sharply along with the rapid population growth and the increasing number of investors both locally and internationally, increasing housing, apartments, hotels, factories, luxury housing. Although there is a tendency for an increase in the number of customers and an increase in the coverage of clean water services in Tangerang District, the service coverage of PDAM TKR (Tirta Kerta Raharja) in Tangerang District is still far below the MDGs (68.90\%) or national target (PDAM TKR Kabupaten Tangerang, 2015).

In 2015, the production capacity of clean water at PDAM TKR was recorded at 5.270 liters per second; the community (Domestic Customers) is allocated approximately 2.270 liters per second (43\%) which includes customers in 20 sub-districts from 29 sub-districts in the Tangerang District. Meanwhile, special customers that working with PDAM TKR receive water distribution of approximately 3.000 liters per second (57\%) as explained in Figure 1 below. 


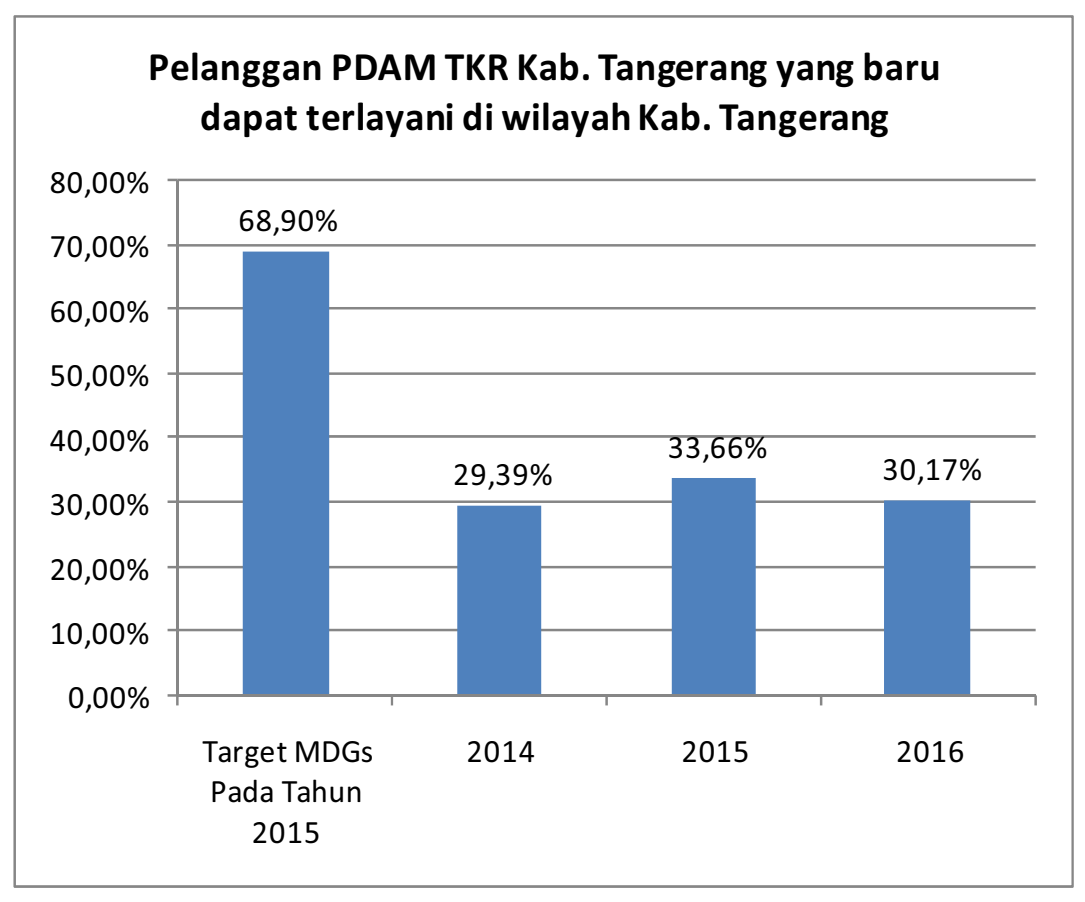

Figure 1. Served Customers of PDAM TKR (Data form PDAM TKR Tangerang District 2016)

Of the $57 \%$ distribution for special customers, a total of 2.800 liters per second is allocated to meet the needs of clean water in DKI Jakarta (15\%). PDAM TKR itself has collaborated with the DKI Jakarta Provincial Government since 1993 and will continue (Tangerangcorner, 2018).

Meanwhile, based on RPJMD document for 2013-2017, the direct connection subscribers will reach $30.17 \%$ of domestic customers (community), where the figure is still below the 40\% target as stated in the Tangerang District RPJMD 2013-2017.

Interestingly, based on the Results of Evaluation of PDAM Region II Performance conducted in 2015 by the BPPSPAM, PDAM TKR is a PDAM that has the title "healthy". The PDAM performance assessment is carried out in a comprehensive manner, covering various aspects. The status, then, has implications for increasing the contribution of PDAM TKR to Tangerang District PAD. 
Table 1. Net Profit Report and Contribution of PDAM TKR in Tangerang District PAD (2011-2015)

\begin{tabular}{cccccc}
\hline \multirow{2}{*}{ Uraian } & $\begin{array}{c}\mathbf{2 0 1 1} \\
\text { (Audited) }\end{array}$ & $\begin{array}{c}\mathbf{2 0 1 2} \\
\text { (Audided) }\end{array}$ & $\begin{array}{c}\mathbf{2 0 1 3} \\
\text { (Audited) }\end{array}$ & $\begin{array}{c}\mathbf{2 0 1 4} \\
\text { (Audited) }\end{array}$ & $\begin{array}{c}\mathbf{2 0 1 5} \\
\text { (Audited) }\end{array}$ \\
\cline { 2 - 6 } & Laba Bersih \\
(Rp.000) & 56.471 .417 & 72.627 .858 & 79.645 .183 & 84.771 .166 & 88.580 .450 \\
$\begin{array}{c}\text { Setoran PAD } \\
(\text { Rp.000) }\end{array}$ & 7.972 .700 & 8.470 .712 & 19.609 .521 & 21.504 .199 & 23.916 .721 \\
\hline
\end{tabular}

Source: PDAM TKR 2015

The positive balance sheet of PDAM TKR can be related to the strategic position of Tangerang District which is one of the DKI Jakarta Province buffer zones and provides an opportunity for the business development of PDAM TKR to distribute clean water to various parties specifically in DKI Jakarta Province. The map of PDAM TKR water distribution can be seen in Figure 2 below.

\section{SISTEM PENYEDIAAN AIR MINUM PDAM TKR}

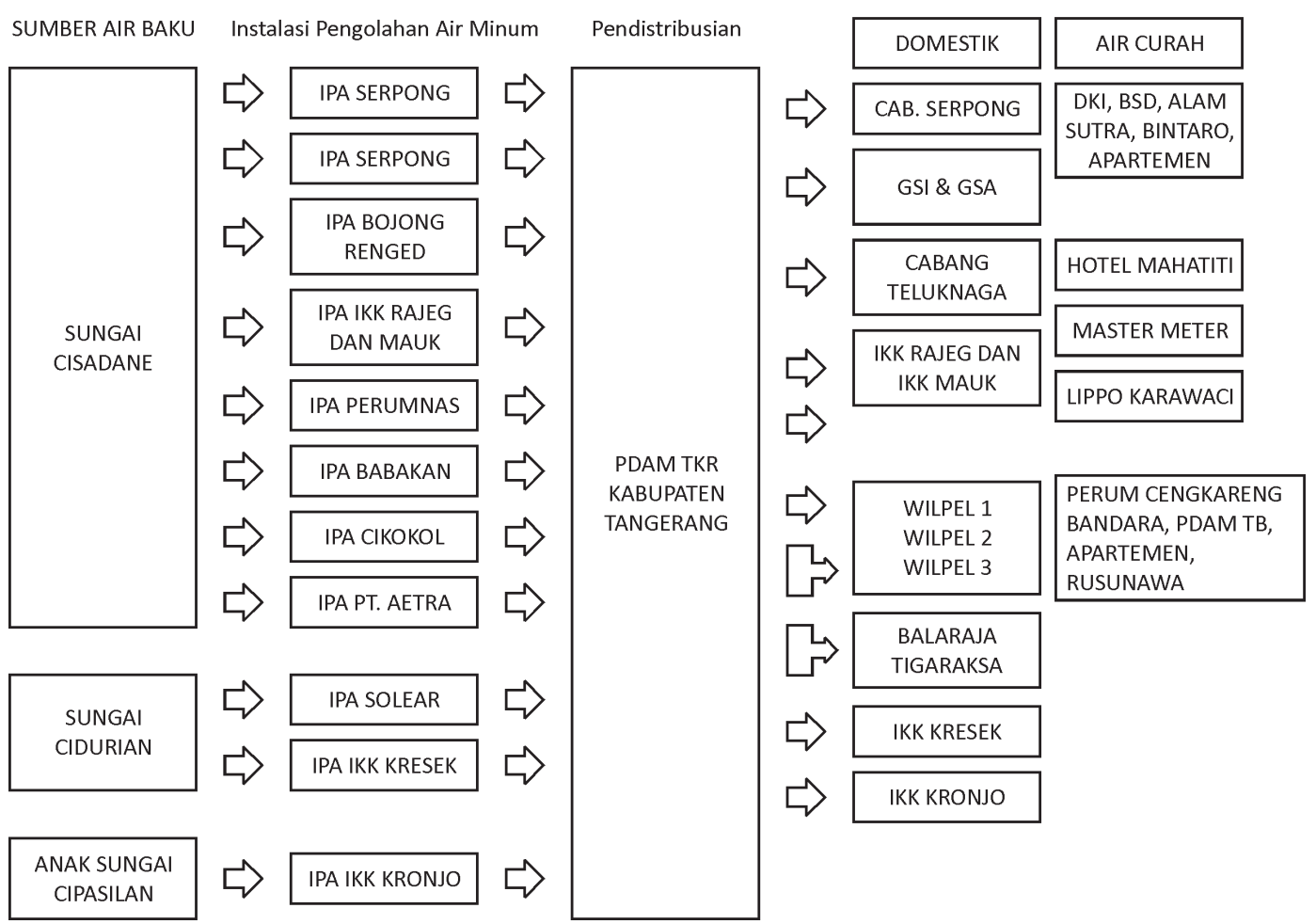

Figure 2. The Map of PDAM TKR Water Distribution Sumber: PDAM TKR 2015 
From the problems raised as described above, this research will focus on the importance of public value in the management of PDAM TKR in Tangerang District which are classified as healthy but face the complexity of problems related to the high acceleration of regional development.

\section{LITERATURE REVIEW}

\section{Public Value}

The concept of public value in Indonesia refers to the desired public value through the establishment of a Public Service Agency (BLU), namely advancing public welfare and educating the life of the nation. The concept of public value requires that leaders of service organizations realize public value through the dynamics of the strategic triangle. That is, in order to create public value, public managers need to understand the three main components of the strategy trilogy which are distinguishing features of public services with services provided by the private sector (Weinberg \& Lewis, 2009; Yotawut, 2018; de Jong, 2015; Cwiklicki, 2016; Benington, 2009).

First, services, the main principles of public service through quality services to meet the needs of the community with the right principles, such as openness, justice and legal certainty. Second, benefits, which include poverty reduction, public health, order and comfort of the city. In this case, the benefits generated by public services are thick with public interests that do not seek profit. The public service will be ambiguous if it is driven by corporate principles, because the benefits of public services prioritize social benefits, sustainable environment, and public order. Third, trust. Every public service organization is formed to maintain and increase public trust in the government by means of more tangible participation and involvement.

Basically, the creation of public value was built based on the strategic triangle popularized by Mark Moore (1995). According to this conception, the task of public managers has something in common in many respects with the task of private sector managers, such as creating economic value for shareholders through the programs implemented. According to Moore (1995) public organizations are considered to create public value if the benefits received by society are greater than the costs incurred, including in terms of the use of legal aspects that force service users to comply with statutory provisions.

In addition, the creation of public value is based on the assumption that public value can be achieved when the decision-making process is based on the existence of a close relationship between the institutional, political and corporate dimensions to ensure joint commitment between the parties in harmony to achieve a common goal. Departing from the theory, to produce public value, public managers are faced with three key questions as follows. 
1. For what organizations are formed?

2. To whom is the organization responsible?

3. How do we know that an organization has successfully achieved its objectives?

To answer the three questions above, public managers need to understand the strategic triangle. This concept is built on a conception of the creation of public value in which the activities of public organizations receive a politically legitimate, operationally and administratively feasible). Providing excellent services and issuing outcomes that are good from the presence of the company and gaining trust from customers will create good public value. The concept of creating public value itself is visualized by the strategic triangle as follows.

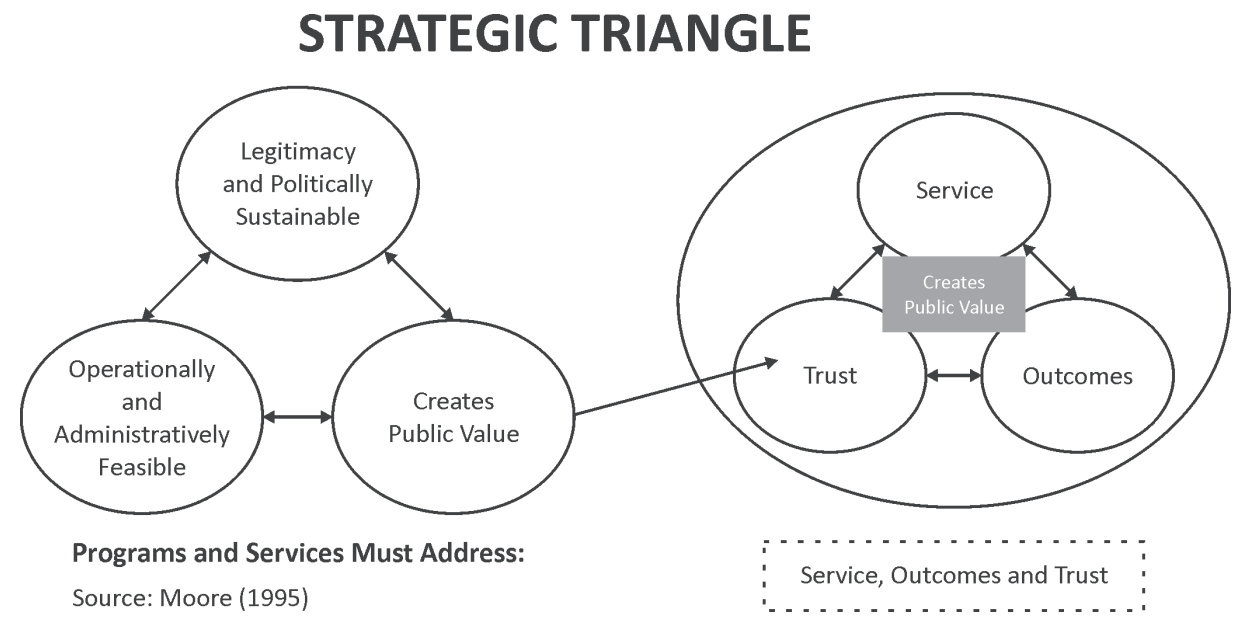

Figure 3. Strategic Triangle (Mark Moore, 1995)

Based on Figure 3 above, it can be said that services have a position that is substantially very valuable. Meanwhile, every organization must also have a vision and mission as the reason why the organization was formed. However, often government leaders are less able to define what organizational goals and objectives are so that the legitimacy and politically sustainable, operational and administratively feasible are not able to create public value. However, the output of the public value in the form of service, outcomes, and trust cannot be produced by the organization.

On the other hand, the existence of a public service body will be tested if there is a change in the government regime. If the organization is maintained by the new government based on the results of democratic and honest elections, it can be said that the public organization has passed one stage of the test as an entity that is expected to create public value (Prasodjo, 2017; Hayat, 2014). 
The success of public service agencies in creating public values is largely determined by the effectiveness of organizations managed with distinctive core competency (Kosasih, 2017 \& 2018; Suweni, et al, 2013).

To achieve high organizational capacity, the leadership of the organization must continue to improve and develop the capabilities of its staff, including employees who are directly involved in the provision of public goods/services. Innovation and creativity of employees is needed by public sector organizations in making public services more qualified and oriented to the community. According to Moore (1995), the success of public sector organizations can be measured by the following factors.

1. Efficiency, effectiveness, and affordability of services by the community;

2. Programs that are appropriate and in accordance with the conditions of the community;

3. The ability of leaders of public organizations articulate the organization's vision and mission into measurable organizational goals and objectives;

4. Reducing dependency or minimizing the burden on the community.

\section{RESEARCH METHOD}

This study uses a qualitative approach to explore what is the cause of ineffective management of PDAM Tirta Kerta Raharja (TKR). Data collection is done through indepth interviews and observations. Informants in this study were selected based on criteria and characteristics: (1) understanding the operational activities of the PDAM's clean water services; (2) integrates with the activities carried out by PDAM TKR; (3) have time to be asked for information by researchers; (4) subjects that do not package information, but relatively provide true information.

Infoman interviewed was divided into internal and external groups at PDAM TKR. There were 6 internal informants from PDAM TKR, which included the Board of Directors, the Head of Engineering, the Head of the General Administration of Finance, the Head of the Subdivision of Public Relations, the Head of Subsection Relationship, and the Subdivision of Distribution. Meanwhile, there were 10 informants from external PDAM TKR, which included the PDAM Supervisory Agency, the Water and Sanitation Development Work Unit in Tangerang District, Domestic Customers, and Nondomestic Customers.

The data analysis refers to the interactive model of Miles-Huberman (1994), which consists of collecting data in the field, reducing data, presenting data, and finally drawing conclusions. For the validity of the data in this study using triangulation, namely by combining data and information obtained from one source with another source by 
examining the suitability of the evidence originating from these sources to obtain understanding and interpretation of problem of the study.

\section{DISCUSSION/ANALYSIS}

\section{Operationally and Administrative Feasibility Aspect}

Basically, PDAM TKR already have a strategic planning concept that is either a corporate plan or a business plan. Strategies in the corporate plan and business plan, called the Corporate Budget Work Plan (RKAP) are prepared annually and are used as operational work plans and investment programs that will be carried out by PDAM TKR for the next one year. This RKAP is also a work guideline that must be followed by the management of PDAM TKR in achieving its stated objectives.

As a PDAM with a healthy title, PDAM TKR has the potential to provide an opportunity for optimal improvement of clean water services, both in terms of quality, quantity, and continuity. This is related to the technical and nontechnical facilities and infrastructure in the company that are quite good. In addition, the program or strategy in the field of human resources (HR) is a special concentration of PDAM PDAM. In order to serve diverse customers, PDAM PDAM prioritize the responsiveness and responsibility of employees in creating good service.

Responsiveness of employees in terms of serving diverse customers is needed; the higher the work responsiveness of PDAM TKR employees, the higher the excellent service provided to customers, for example by responding and handling complaints properly. Responsibility of employees must also be good in terms of carrying out tasks so that the public services provided do not necessarily violate the provisions set by the organization. That is, employees have the responsibility of carrying out the decrees made and determined by the board of directors. In this case, researchers argue that human resources (HR), methods or approaches, completeness of tools (machines), and materials are service strategies that cannot be separated each other.

When referring to the concept of public value, it can be said that the operationally aspect and administrative feasibility of PDAM TKR still have many shortcomings, due to lack of reliable human resources that have not been able to serve customers well. This is due to the lack of intense employee training programs and the placement of human resources that are not in accordance with their fields of expertise.

\section{Creates Public Value Aspect}

The creation of public value is based on the assumption that public value can be achieved when the decision making process is based on the existence of a close relationship between the institutional, political and corporate dimensions to ensure that there is a 
joint commitment between the parties involved in achieving the goals together. In this case, PDAM TKR has made every effort to be able to create good public value, starting from institutional aspects, political policies to corporations that are carried out professionally by the company.

To find out the public value of PDAM TKR, there are three aspects in the theory of public value: service, outcomes, and trust. In providing services for diverse customers, PDAM TKR strives to provide excellent service, one of which is carried out through onlinebased services that are easily accessible, such as water meter reading using Android Meter Reading, bill payments, new connection services, complaints through contact center, and the implementation of installation for new subscription connections has been fully stocked.

This online-based service is one of the efforts of PDAM TKR to provide the best service for its customers. However, the reality in the field shows that customer satisfaction is still not a major concern, which for example can be seen from the number of complaints from customers related to water distribution to homes, disruption to water meters, plots (pipe connections from water meters to customers) or leaks in customer pipes and poor water quality. This customer complaint is usually delivered by calling directly to PDAM TKR office or reporting directly to PDAM TKR customer service department. Unfortunately, this customer complaint is often delayed by PDAM TKR; there are customers who must repeatedly contact PDAM TKR or come back repeatedly until the complaint is followed up. In addition to complaints from domestic customers (communities), there are also complaints from various companies that work with PDAM TKR.

Meanwhile, the main function of PDAM is to prioritize public service delivery in providing clean water needs (social functions) in addition to seeking profit as a function of the company or business functions; another function is to provide services and provide public benefits in the drinking water sector for the public interest. Therefore, the aim of PDAM is not only to seek profit, but also to create maximum benefits for the community.

Based on the main functions of Local Water Supply Utility (PDAM), PDAM TKR as a public service company, the outcomes in the management and service aspects that are held must be felt directly, both economically and socially for the community in helping supply drinking water. Creating public value for PDAM TKR, in addition to providing good service, the benefits directly felt by the community as outcomes for the company are one of the ways in which public values are formed.

Meanwhile, as a public company in terms of outcomes (results), the presence of PDAM TKR has also been felt by the people living in the coastal areas of Tangerang District, such as Mauk Subdistrict, Teluk Naga, Kosambi, and Kronjo, which need clean water and water drink good in their lives. 
The benefits felt by the people in this coastal area are one of the outcomes that can be felt from the presence of PDAM TKR. In addition, clean water services at affordable prices are also one of the outcomes that can be felt by customers in fulfilling clean water needs (as a social function) in addition to seeking profit as a function of the company or business functions. PDAM TKR has also undergone other social functions by fulfilling clean water needs through tank cars in various areas that experience drought every dry season.

However, this study also found that there are still regions that have not yet benefited from the presence of PDAM TKR, such as Sukamulya Subdistrict which has not yet connected the water pipeline. As a company that provides clean water needs (social functions), of course these shortcomings must be addressed immediately so that the public value of PDAM TKR can be realized well.

The other dimension is trust. In general, trust is the existence of trust by the first party (one party) to the second party (another party) that the second party will behave that can bring positive results for the first party. The substance of trust can be divided into two; (1) the honesty of the partner (trust is the partner's honesty) which includes the trust of the first party to his partner that his partner will fulfill his pledged promise; and (2) the good deed of the partner to what extent the first party believes that the second party is truly interested in the welfare of the first party. Therefore, customer trust in the company includes how company behaves (honesty, integrity, capability, consistency, and various other performances that can shape customer trust).

To create public value, the trusts that obtained from customers are closely related to services and outcomes so giving rise to trust and obtaining public value for PDAM TKR. In general, PDAM TKR get a fairly good public value from their customers so that it has a good impact on the trust of PDAM TKR from customers. One of them is proven or can be seen from the number of PDAM TKR customers's which continues to increase every year. Customers who increase every year certainly cannot be separated from the hard work of the company to serve customers well so that trust can grow in the community.

The automatic increase in the number of customers provides benefits for PDAM TKR because of an increase in net income every year. This new customer contributes greatly to the increase in profit of PDAM TKR so that PDAM TKR can improve its services for the community and ultimately get trust from the community.

In addition to increasing the number of customers every year, trust can be seen from customer complaint report data which decreases every year as can be seen in Table 2 below. 
Table 2. Customer Complaint Report

\begin{tabular}{ccccc}
\hline No & Tahun & $\begin{array}{c}\text { Laporan Keluhan } \\
\text { Teknis }\end{array}$ & $\begin{array}{c}\text { Laporan Keluhan } \\
\text { Nonteknis }\end{array}$ & Jumlah Total \\
\hline 1 & 2014 & 7.093 & 393 & 7.486 \\
2 & 2015 & 4.698 & 475 & 5.173 \\
3 & 2016 & 1.277 & 3.510 & 4.787 \\
\hline
\end{tabular}

\section{Source: PDAM TKR 2016}

From Table 2 above, it can be seen how for three consecutive years customer complaints against PDAM TKR decline. This means that customers have put their trust in PDAM TKR, where complaints can be responded quickly so that they can create good public value for PDAM TKR.

However, this study also found that there were still areas where the level of trust in PDAM TKR was reduced, such as some customers who disconnect due to several reasons, poor response to customer complaints, slow handling of damaged water connections.

From these explanations, services, outcomes, and trust are an inseparable unit. If one of them is good, it will affect the others. Likewise, on the contrary, if one of them is bad, it will have a negative impact on the other. So, the public value of the company (PDAM TKR) must be seen as a whole. At PDAM TKR, the public value built in the eyes of the community has not reached its maximum, especially because there are still various aspects that need to be improved, both from the management and service aspects to create excellent service.

\section{CONCLUSION}

In improving the service of public companies, besides having to pay attention to excellent management and service, the activities of public organizations must politically legitimate, operationally and administratively feasible so as to creates positive public value that originating from service, outcomes, and trust. In this study, the public value of PDAM TKR has not been internalized optimally, and it requires adaptation to various changes within the organization. In addition, the diverse customer characteristics of PDAM TKR require specific strategies to respond to their needs. 


\section{REFERENCES}

Benington, J. (2009). "Creating The Public in Order to Create Public Value?" International Journal of Public Administration, 32(3-4): 232-249. http://doi.org/10.1080/ 01900690902749578.

Cwiklicki, Marek. (2016). “Comparison of Public Value Measurement Frameworks". Zarz¹zanie Publiczne, 1(35): 20-32.

de Jong, Jorrit. (2015). “Instruments of Value: Using the Analytic Tools of Public Value Theory in Teaching and Practice". Public Management Review, 19: 605-620. doi: 10.1080/ 14719037.2016.1192162

Hayat. (2014). “Konsep Kepemimpinan dalam Reformasi Birokrasi: Aktualisasi Pemimpin dalam Pelayanan Publik Menuju Good Governance". Jurnal Borneo Administrator, 10(1): 59-84.

Kementerian Pekerjaan Umum dan Perumahan Rakyat. (09 April 2018). Cipta Karya Mengalokasikan DAK Tahun 2018 Rp. 2.160 Miliar Untuk Air Minum. Diakses dari: https:/ / www.pu.go.id/berita/view/15556/cipta-karya-mengalokasikan-dak-tahun2018-rp-2-160-miliar-untuk-air-minum

Kementerian Pekerjaan Umum dan Perumahan Rakyat. (2017). Buku Kinerja PDAM 2017. Jakarta: BPPSPAM Kementerian PUPR.

Kementerian Pekerjaan Umum dan Perumahan Rakyat. (22 Februari 2018). Ditjen Cipta Karya Gandeng Kemenko Perekonomian Untuk Capai Target 100\% Akses Air Minum. Diakses dari: https://www.pu.go.id/berita/view/15353/ditjen-cipta-karya-gandengkemenko-perekonomian-untuk-capai-target-100-akses-air-minum

Kosasih, Achmad. (2017). “Pengaruh Kepemimpinan Transformasional, Budaya Organisasi dan Motivasi Kerja Pegawai terhadap Kepuasan Kerja Pegawai serta Implikasinya pada Kinerja Pegawai PDAM di Propinsi Banten". Journal of Government and Civil Society, 1(2): 159-190.

Kosasih, Achmad. (2018). “Optimalisasi Pelayanan Publik melalui Peningkatan Kinerja Pegawai pada PDAM Tirta Kerta Raharja". Journal of Government and Civil Society, 2(1): 51-62.

Moore, Mark H. (2015). Creating Public Value: Strategic Management in Government. Harvard University Press.

PDAM TKR Kabupaten Tangerang Lanjutkan Suplai 15 Persen Air Bersih DKI Jakarta. (14 Februari 2018). Diakses dari: https://tangerangcorner.com/pdam-tkr-kabupatentangerang-lanjutkan-suplai-15-persen-air-bersih-dki-jakarta/

Prasodjo, Tunggul. (2017). "Paradigma Humanis dalam Pelayanan Publik". Jurnal Ilmiah Ilmu Administrasi Publik, 7(1): 38-45.

Suweni, Jefri Maikel, dkk. (2013). “Analisis Pengaruh Faktor Kemampuan Manajerial Pemberian Insentif dan Komunikasi Pemimpin terhadap Prestasi Kerja". Jurnal Pelopor, 6(2): 11-21. 
Weinberg, Mark L. \& Marsha S. Lewis. (2009). “The Public Value Approach to Strategic Management". Museum Management and Curatorship, 24(3): 253-269.

Yotawut, Mayuree. (2018). “Examining Progress in Research on Public Value". Kasetsart Journal of Social Sciences, 39(1): 168-173. 
